\title{
PENGARUH BI RATE, INFLASI, FLUKTUATIF KURS DAN VOLUME PERDAGANGAN SAHAM TERHADAP INDEKS HARGA SAHAM GABUNGAN PERIODE 2009-2017
}

\author{
Herlina \\ Program Studi Magister Manajemen Universitas Tarumanagara \\ Jc.herlina@gmail.com \\ Indra Widjaja \\ Program Studi Magister Manajemen Universitas
}

\begin{abstract}
The capital market is the liaison between investors and companies or within the government. Over the past few years, stock prices in Indonesian stocks have shown improved performance. JCI movement reflects the financial condition of business companies in Indonesia. Changing conditions can give positive or negative information on commercial transactions. Based on the results of the research, simultaneous macro variables are BI Rate, inflation, volume and trading volume that have a significant influence on JCI with sig value of $0.000<0.01$. While partially, BI rate and trading volume have a significant influence on JCI with BI sig rate of $0.000<0,05$ and trading volume sig $0.002<0.01$. The exchange rate and the exchange rate have no influence on the JCI with the sig value of inflation of $0.940>$ 0.05 and the fluctuating sig exchange rate of $0.584>0.05$.
\end{abstract}

Keywords: JCI, BI rate, inflation, exchange rate, stock trading volume

\section{PENDAHULUAN}

Pada masa kini persaingan dunia bisnis dan ekonomi semakin ketat dan kuat. Hal ini menjadi pemicu bagi perusahaan untuk membenahi manajemen dan kualitas untuk meningkatkan performa perusahaan sehingga dapat menarik minat investor berinvestasi di perusahannya. Pasar modal merupakan pasar untuk berbagai instrumen keuangan jangka panjang penghubung antara investor denganbaik dalam bentuk utang, ekuitas (saham), instrumen derivatif, maupun yang bisa diistrumen lainnya. pasar modal merupakan sarana untuk menghimpun dana bagi perusahaan atau institusi pemerintah dan sebagai sarana untuk berinvestasi. Seiring dengan meningkatnnya aktivitas perdagangan di pasar modal, maka dibutuhkan informasi yang lengkap yang dapat diakses masyarakat mengenai perkebangan volume perdagangan dipasar modal. Salah satu informasi yang diperlukan adalah Indeks harga saham (IHSG). Pergerakan Indeks Harga Saham Gabungan (IHSG) dipengaruhi oleh tiga faktor yaitu faktor domestik, asing, dan faktor aliran modal ke Indonesia. Faktor domestik meliputi tingkat suku bunga, nilai tukar rupiah, tingkat inflasi, jumlah uang yang beredar, dan sebgainya.

Perkemmbangan Indekss Harga Saham dari tahun ke tahun mengalami peningkatan. Peningkatan ini tidak lepas dari ketiga faktor utama pergerakan Indekss harga saham. Berdasarkan hasil penelitian Praphan (2002), terdapat hubungan jangka panjang dan jangka pendek antara harga saham dan variabel makroekonomi. Harga saham berinteraksi dengan variabel makroekonomi utama baik dalam jangka panjang maupun jangka pendek, dimana kebijakan ekonomi dan keuangan pemeintah memiliki andil dalam pergerakan harga saham. Senada dengan Noviatin (2013), terdapat beberapa hubungan kausalitas satu arah antara variabel makroekonomi dan IHSG pada periode penelitian. Sangkyun (1997), secara umum, pengaruh relatif dari berbagai variabel ekonomi terhadap tingkat pengembalian saham. 
Kebijakan tingkat suku bunga di Indonesia secara langsung dikendalikan oleh Bank Indonesia. Tugas Bank Indonesia adalah menstabilkan ekonomi makro dengan melakukan perubahan menaikan atau menurunkan suku bunga. Suku bunga Bank Indonesia atau dikenal dengan BI Rate. BI Rate merupakan suku bunga kebijakan moneter yang diciptakan oleh Bank Indonesia dalam merespon tekanan inflasi dan ekonom makro lainnya. Perubahan BI Rate memicu pergerakan di pasar saham di Indonesia. Hasil penelitian Yogaswari (2012) mengenai pengaruh variabel makro ekonomi terhadap Indekss harga saham gabungan menyatakan bahwa BI Rate memberikan pengaruh negative secara signifikan terhadap Indekss harga saham gabungan. Hasil penelitian ini bertolak belakang dengan penelitian. Kowanda (2015) menyatakan bahwa BI Rate berpengaruh secara tidak signifikan terhadap Indekss harga saham gabungan.

Demikian juga dengan tingkat inflasi yang merupakan proses menningkatnya hargaharga secara umum dan terus menerus atau menurunnya nilai mata uang secara kontinu. Perubahan inflasi berkaitan dengan konsumsi masyarakat, ketersediaan barang, adanya permintaan alat tukar atau uang atau kelebihan liquiditas, spekulasi dan proses distribusi akibat ketidaklancaran distribusi barang.

Perubahan inflasi selama kurun waktu tiga tahun masih tergolog stabil, tingkat inflasi tinggi biasanya dikaitkan dengan kondisi ekonomi yang terlalu panas. Tingkat inflasi tinggi ditandai degan menurunnya daya beli masyakat, yang menyebabkan pendapatan riil perusahaan berkurang. Penurunan pendapatan perusahaan berdampak pada Indeks Harga Saham perusahaan tersebut. Penurunan harga saham perusahaan secara serentak mengakibatkan gejolak pada pergerakan Indekss Harga Saham Gaungan (IHSG). Hasil penelitian Alianty (2016) menyatakan bahwa inflasi tidak memiliki pengaruh yang signifikan terhadap Indeks harga saham. Hasil penelitian tersebut bertolak belakang dengan penelitian Yogaswari (2012) yang menguji variabel makro ekonomi bahwa inflasi memberikan pengaruh yang positif dan signifikan terhadap Indekss harga saham gabungan.

Mata uang merupakan alat transaksi ekonomi yang digunakan oleh suatu negara baik dalam transaksi nasional maupun internasional. Salah satu mata uang umum di dunia adalah mata uang Dollar Amerika (US\$). Indonesia merupakan negara berkembang, dimana negara berkembang masih mudah terdeprsiasi oleh mata uang negara maju seperti Amerika Serikat. Nilai tukar rupiah menguat jika harga per Dollar AS mengalami penurunan dan nilai tukar rupiah melemah jika harga per Dollar AS mengalami kenaikan. Bagi perusahaan perusahaan yang aktif dalam perdagangan internasional, berharap nilai tukar (kurs) selalu stabil terhadap rupiah karena dapat mempengaruhi pendapatan riil perusahaan. Perubahan kurs secara bersama sama dapat menyebabkan pergerakan Indeks harga saham. Berdasarkan hasil penelitian Kewal (2012) menyatakan bahwa kurs memiliki pengaruh yang signifikan terhadap Indeks harga saham. Hasil penelitian Alianty (2016) menyatakan bahwa kurs tidak memiliki pengaruh yang signifikan terhadap Indeks harga saham.

Demikian juga dengan volume tansaksi perdagangan saham. Jika harga saham mengalami kenaikan menunjukkan bahwa kondisi ekonomi mengalami peningkatan perbaikan kinerja perekonomian. Namun jika harga saham turun menunjukkan bahwa kondisi ekonomi lesu atau ekonomi sedang dalam masalah. Kenaikan harga saham belum tentu membuat volume perdagangan saham mengalami kenaikan demikian juga sebaliknya. Berdasarkan hasil penelitian Murwaningsari (2008), hasil penelitian menyatakan bahwa volume perdagangan memiliki pengaruh yang positif terhadap Indeks harga saham. Fikri \& Andini (2012), hasil penelitian menyatakan bahwa volume perdagangan memiliki pengaruh yang positif terhadap Indeks harga saham.

Berdasarkan uraian diatas, terdapat kesenjangan dan beberapa hasil penelitian. Oleh karena itu penelitian ini akan mengnalisis kembali "Pengaruh BI Rate, Inflasi, Fluktuatif Kurs 
dan Volume Perdagangan Saham Terhadap Indeks Harga Saham Gabungan Periode 20092017".

\section{TINJAUAN PUSTAKA}

Indeks harga saham gabungan (IHSG) merupakan satu dari beberapa jenis pasar saham yang dipakai oleh bursa efek Indonesia. IHSG digunakan sebagai indikator yang menggambarkan pergerakan harga saham di bursa efek secara umum. Menurut Widoatmojo (2005:238), untuk bisa melakukan investasi di pasar modal dengan baik, perlu mengetahui apa yang disebut Indekss harga saham. Sebuah fenomena dapat memberikan keuntugan positif dan negatif bagi perusahaan. Menurut Samsul (2008) dalam Kowanda (2015) banyak faktor yang mempengaruhi pergerakan Indeks saham di suatu negara, antara lain tingkat suku bunga domestik, kurs valuta asing, kondisi perekonomian internasional, siklus ekonomi suatu negara, tingkat inflasi, peraturan perpajakan, dan jumlah uang yang beredar.

BI Rate adalah suku bunga kebijakan bank Indonesia dan diumumkan kepada publik. Dalam menetapkan kebijakan suku bunga, Bank Indonesia mempertimbangkan faktor-faktor lain dalam perekonomian. Berdasarkan hasil penelitian Budiantara (2012), menunjukkan bahwa variabel tingkat suku bunga berpengaruh secara negatif dan signifikan terhadap harga saham. Berdasarkan hasil penelitian Kandir (2008), menunjukkan bahwa empirical findings reveal that interest rate to affect all of the portfolio returns. Kowanda (2015), BI Rate berpengaruh tetapi tidak signifikan signifikan terhadap IHSG.

Inflasi diartikan sebagai meningkatnya harga-harga secara berkelanjutan dan meluas yang menyebabkan turunnya nilai mata uang dalam negeri. Indikator yang sering digunakan untuk mengukur tingkat inflasi adalah Indekss Harga Konsumen (IHK). Menurut Tandelilin (2001:214), peningkatan inflasi secara relatif merupakan sinyal negatif bagi pemodal di pasar modal. Menurut Samsul (2006, 201), "tingkat inflasi dapat berpengaruh positif ataupun negatif tergantung pada derajat inflasi itu sendiri. Inflasi yang berlebihan dapat merugikan secara keseluruhan yaitu dapat membuat banyak perusahaan mengalami kebangkrutan. Alianty (2016), menunjukan bahwa inflasi memiliki pengaruh terhadap IHSG. Kewal (2012), menunjukkan bahwa inflasi tidak berpengaruh terhadap IHSG. Hasil penelitian Kowanda (2015), inflasi berpengaruh tetapi tidak signifikan signifikan terhadap IHSG.

Noviatin (2013) Nilai tukar (kurs) adalah sejumlah mata uang lokal yang dibutuhkan untuk membeli satu unit mata uang asing. Handiani (2014), menyebutkan bahwa nilai tukar adalah suatu perbandingan antara nilai mata uang suatu negara dengan negara lain. Mata uang setiap negara memiliki harga tertentu dalam mata uang negara lain. Harga tersebut menggambarkan berapa banyak suatu mata uang harus dipertukarkan untuk memperoleh satu unit mata uang lain. Berdasarkan hasil penelitian Kewal (2012), menunjukkan bahwa kurs Rupiah terhadap Dollar Amerika memiliki pengaruh yang negatif dan signifikan terhadap IHSG. Hasil penelitian Handiani (2014), Nilai Tukar USD/IDR berpengaruh secara positif sebesar 0,168 terhadap Indekss Harga Saham Gabungan pada periode 2008-2013. Hasil penelitian Kowanda (2015), nilai Tukar Rupiah terhadap USD berpengaruh secara signifikan terhadap IHSG. Hasil penelitian Handiani (2014), nilai Tukar USD/IDR berpengaruh terhadap Indekss Harga Saham Gabungan pada periode 2008 - 2013.

Ying (1966) dalam Murwaningsari (2008), meneliti hubungan antara harga saham dan volume perdagangan saham yang didasarkan pada anggapan bahwa keduanya merupakan produk bersama mekanisme pasar, menyim-pulkan antara lain : (1) ketika volume perdagangan saham terus menurun, harga biasanya jatuh; (2) ketika volume perdagangan terus menerus membesar, biasanya harga saham akan naik; (3) apabila volume perdagangan mulai menurun secara berurutan selama 5 hari perdagangan, maka akan ada suatu tendensi bagi harga akan jatuh selama 4 hari perda-gangan berikutnya; (4) apabila volume perda-gangan 
mulai meningkat secara berurutan selama 5 hari perdagangan, maka akan ada suatu tendensi bagi harga untuk naik selama 4 hari perdagangan berikutnya.

\section{METODOLOGI PENELITIAN}

Jenis penelitian ini merupakan penelitain kuantitatif asosiatif. Penelitian ini merupakan kuantitatif yang menggunakan rumus korelasi dan regresi linier berganda.Sumber data merupakan data eksternal berupa time series. Sampel penelitian ini 36 data triwulan tahun 2009-2017.

Dalam penelitian ini terdapat empat uji sebagai prasyarat yaitu 1) uji normalitas digunakan mengetahui apakah data berdistribusi normal. Pengujian menggunakan uji kolmogorov-smirnov. Jika probabilitas (sig.) $>\alpha(5 \%)$, maka data berdistribusi normal, dengan tingkat kepercayaan 95\%. 2)multikolinearitas adalah keadaan dimana antara dua variabel independent atau lebih pada model regresi terjadi hubungan linier yang sempurna atau mendekati sempurna. Mendeteksi ada tidaknya multikolinearitas dengan melihat nilai VIF lebih kecil dari 10 dan tolerance lebih dari 0,1 sehingga dapat disimpulkan tidak terdapat multikolinieritas. 3)heterokedastisitas adalah keadaan dimana terjadinya ketidaksamaan varian dari residual pada model regresi. Untuk mendeteksi ada tidaknya heterokedastisitas dengan melihat pola titik-titik pada scatterplots regresi pada output SPSS. Jika titik-titik menyebar secara tidak jelas atau tidak membentuk pola maka tidak terjadi heterokedastisitas. 4) autokorelasi adalah keadaan dimana terjadinya korelasi dari residual untuk pengamatan satu dengan pengamatan lain yang dususun menurut runtun waktu, tidak terdapat autokorelasi jika dU $<\mathrm{dw}<4-\mathrm{dU}$ maka tidak terjadi autokorelasi. Duwi Priyatno (2013:61). Menurut Sufren (2013:109), tidak terdapat autokorelasi jika nilai dw terletak pada $1<\mathrm{dw}<3$

Uji F dalam SPSS dapat dilihat pada table ANOVA (Analysis of Variance) dan kriteria pengambilan keputusan, jika probabilitas (sig.) $>\alpha(5 \%)$ maka tidak ada pengaruh yang signifikan secara simultan variabel $\mathrm{X} 1, \mathrm{X} 2$ dst terhadap variabel $\mathrm{Y}$, dengan tingkat kepercayaan 95\%. Uji t dalam SPSS dapat dilihat pada table coefficients dan kriteria pengambilan keputusan, jika probabilitas (sig.) $>\alpha(5 \%)$, maka tidak ada pengaruh yang signifikan antara variabel terhadap variabel $\mathrm{Y}$, dengan tingkat kepercayaan $95 \%$.

\section{HASIL DAN PEMBAHASAN}

Analisis data yang dilakukan menggunakan analisis regresi berganda dengan bantuan program SPSS 22. Hasil uji asumsi klasik dijelaskan secara rinci sebagai berikut:

Tabel 1 Uji Multikolinearitas

\begin{tabular}{llrr} 
& \multicolumn{3}{c}{ Collinearity Statistics } \\
\cline { 3 - 4 } & & Tolerance & VIF \\
\hline \multirow{2}{*}{1} & Lag_Inflasi &, 251 & 3,986 \\
\cline { 2 - 4 } & BI Rate &, 147 & 6,811 \\
\cline { 2 - 4 } & Fluktuatif Kurs &, 788 & 1,269 \\
\cline { 2 - 4 } & Volume Penjualan Saham &, 177 & 5,663 \\
\hline
\end{tabular}

Berdasarkan Tabel 1, menunjukkan bahwa nilai VIF <10 dan Tolerance $>0,1$ maka antar variabel bebas tidak memiliki hubungan yang sempurna dengan kata lain model regresi terbebas dari multikolinearitas. 


\section{Tabel 2 Uji Autokorelasi}

\begin{tabular}{|c|c|c|c|c|c|}
\hline Model & $\mathrm{R}$ & R Square & $\begin{array}{r}\text { justed R } \\
\text { Square }\end{array}$ & $\begin{array}{r}\text { Std. Error of the } \\
\text { Estimate }\end{array}$ & $\begin{array}{l}\text { Durbin- } \\
\text { Watson }\end{array}$ \\
\hline 1 &, $583^{\mathrm{a}}$ & ,340 &, 255 & 978,7984834056866 & ,401 \\
\hline
\end{tabular}

Berdasarkan Tabel 2, menunjukkan bahwa nilai durbin watson sebesar 0,401 dengan sampel sebanyak 36 dan jumlah semua variabel sebanyak 5 maka nilai $\mathrm{dL}=1,1755$ dan $\mathrm{dU}$ $=1,7987$ maka dw < dL sehingga terdapat autokorelasi.

Pengobatan autokorelasi melakukan transformasi Lag pada variabel residual. Lag artinya mengembalikan variabel baru yang merupakan hasil pengurangan nilai dari sampel ke-i dikurangi sampel ke-i -1 .

\section{Tabel 3 Koefisien Autokorelasi (rho)}

\begin{tabular}{|c|c|c|c|c|c|c|}
\hline & \multirow[b]{2}{*}{ Model } & \multicolumn{2}{|c|}{$\begin{array}{r}\text { Unstandardized } \\
\text { Coefficients }\end{array}$} & \multirow{2}{*}{$\begin{array}{r}\begin{array}{r}\text { Standardized } \\
\text { Coefficients }\end{array} \\
\text { Beta }\end{array}$} & \multirow[b]{2}{*}{$\mathrm{t}$} & \multirow[b]{2}{*}{ Sig. } \\
\hline & & B & Std. Error & & & \\
\hline 1 & Lag_e & ,714 &, 098 &, 782 & 7,305 &, 000 \\
\hline
\end{tabular}

Maka koefisien autokorelasi $(\rho)=0,782$. Selanjutnya melakukan transformasi Cochrane Orcutt dengan rumus variabel $x-(0,782 *$ Lag (variabel $x))$. Berikut hasil pengolahannya:

Tabel 4 Transformasi Uji Autokorelasi

\begin{tabular}{lrrrrr}
\hline Model & R & R Square & $\begin{array}{c}\text { Adjusted R } \\
\text { Square }\end{array}$ & $\begin{array}{c}\text { Std. Error of } \\
\text { the Estimate }\end{array}$ & Durbin-Watson \\
\hline 1 &, $955^{\text {a }}$ &, 912 &, 900 & 341,198564303 & 1,127 \\
\hline
\end{tabular}

Berdasarkan Tabel 4, menunjukkan bahwa nilai durbin watson sebesar 1,127 dengan sampel sebanyak 36 dan jumlah semua variabel sebanyak 5 maka nilai $\mathrm{dL}=1,1755$ dan $\mathrm{dU}$ $=1,7987$. Hasil perhitungan menunjukkan bahwa $\mathrm{dL}<\mathrm{dw}<\mathrm{dU}=1,1755<\mathrm{dw}<1,7987$ maka memiliki arti tidak dapat disimpulkan. Namun jika menurut Sufren (2013:109), tidak terdapat autokorelasi jika nilai $\mathrm{dw}$ terletak pada $1<\mathrm{dw}<3$. Maka nilai $\mathrm{dw}=1,127$ artinya tidak terdapat autokorelasi.

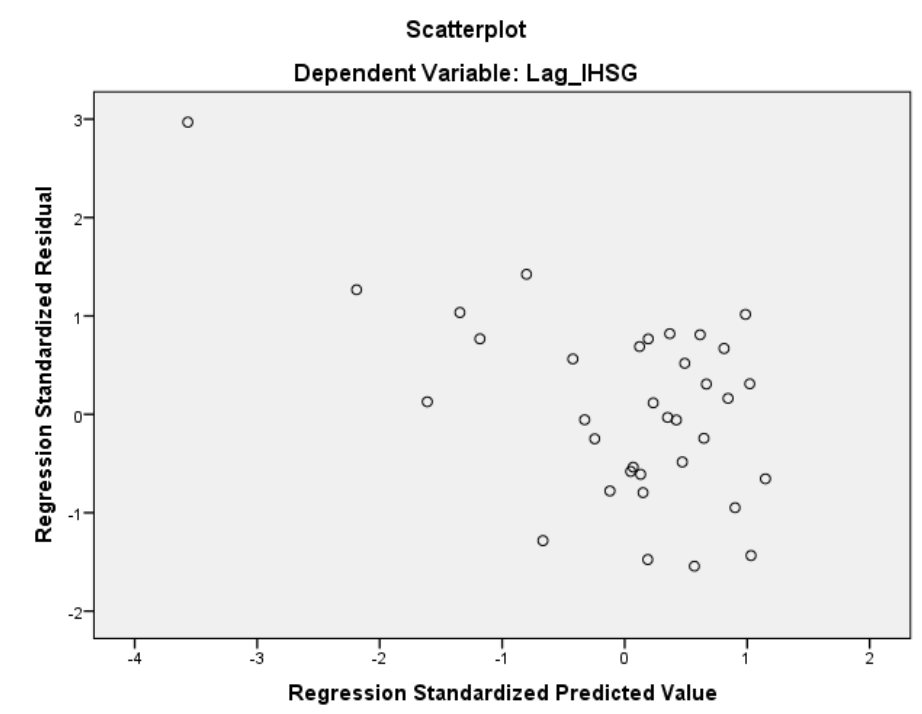

Gambar 1 Uji Heterokedastisitas

Berdasarkan Gambar 1, titik titik tidak berpola, sehingga data terbebas dari heterokedastisitas.

Tabel 5 Uji Normalitas

Kolmogorov-Smirnov ${ }^{\mathrm{a}} \quad$ Shapiro-Wilk




\begin{tabular}{lrrrrrr}
\hline & Statistic & df & \multicolumn{1}{c}{ Sig. } & Statistic & df & \multicolumn{1}{c}{ Sig. } \\
\hline Lag_Inflasi &, 102 & 35 &, $200^{*}$ &, 969 & 35 &, 419 \\
\hline Lag_IHSG &, 080 & 35 &, $200^{*}$ &, 974 & 35 &, 566 \\
\hline BI Rate &, 140 & 35 &, 080 &, 943 & 35 &, 069 \\
\hline $\begin{array}{l}\text { Volume Perdagangan } \\
\text { Saham }\end{array}$ &, 123 & 35 &, 198 &, 959 & 35 &, 214 \\
\hline Fluktuatif Kurs &, 137 & 35 &, 094 &, 934 & 35 &, 038 \\
\hline
\end{tabular}

Berdasarkan Tabel 5, menunjukkan bahwa semua variabel nilai sig >0,05 sehingga semua variabel berdistribusi normal.

Berikut hasil pengolahan kontribusi dan pengaruh BI-rate, Inflasi, Fluktuatif Kurs dan Volume Perdagangan saham terhadap IHSG

Tabel 6 Kontribusi BI-rate, Inflasi, Fluktuatif Kurs dan Volume Perdagangan saham terhadap IHSG

\begin{tabular}{llrrrr}
\hline Model & R & R Square $^{\mathrm{b}}$ & $\begin{array}{c}\text { Adjusted R } \\
\text { Square }\end{array}$ & $\begin{array}{c}\text { Std. Error of the } \\
\text { Estimate }\end{array}$ & Durbin-Watson \\
\hline 1 &, $955^{\mathrm{a}}$ &, 912 &, 900 & 341,198564303 & 1,127 \\
\hline
\end{tabular}

Berdasarkan Tabel 6, kotribusi BI rate, inflasi, fluktutif kurs dan volume perdagangan saham dalam menjelaskan IHSG sebesar 91,2\% dan sisanya dijelaskan oleh variabel lain.

Tabel 7 Uji Global

\begin{tabular}{|c|c|c|c|c|c|c|}
\hline Model & & $\begin{array}{l}\text { Sum of } \\
\text { Squares }\end{array}$ & $\mathrm{df}$ & Mean Square & $\mathrm{F}$ & Sig. \\
\hline \multirow[t]{3}{*}{1} & Regression & 37299088,858 & 4 & 9324772,214 & 80,098 &, $000^{\mathrm{c}}$ \\
\hline & Residual & 3608910,269 & 31 & 116416,460 & & \\
\hline & Total & $40907999,127^{\mathrm{d}}$ & 35 & & & \\
\hline
\end{tabular}

Berdasarkan Tabel 7, nilai sig sebesar 0,000 <0,01 maka memiliki arti bahwa BI rate, inflasi, fluktutif kurs dan volume perdagangan saham perdagangan saham memiliki pengaruh yang sangat signifikan terhadap IHSG.

Tabel 8 Uji Parsial

\begin{tabular}{|c|c|c|c|c|c|c|c|c|}
\hline \multirow{2}{*}{\multicolumn{2}{|c|}{ Model }} & \multicolumn{2}{|c|}{$\begin{array}{l}\text { Unstandardized } \\
\text { Coefficients }\end{array}$} & \multirow{2}{*}{$\begin{array}{c}\begin{array}{c}\text { Standard } \\
\text { ized } \\
\text { Coeffici } \\
\text { ents }\end{array} \\
\text { Beta }\end{array}$} & \multirow[b]{2}{*}{$\mathrm{t}$} & \multirow[b]{2}{*}{ Sig. } & \multicolumn{2}{|c|}{$\begin{array}{l}95,0 \% \text { Confidence } \\
\text { Interval for B }\end{array}$} \\
\hline & & B & Std. Error & & & & $\begin{array}{l}\text { Lower } \\
\text { Bound }\end{array}$ & $\begin{array}{l}\text { Upper } \\
\text { Bound }\end{array}$ \\
\hline 1 & Lag_Inflasi & $-51,080$ & 675,840 &,- 008 &,- 076 &, 940 & $-1429,464$ & 1327,304 \\
\hline & BI Rate & 93,626 & 23,238 & ,561 & 4,029 &, 000 & 46,231 & 141,020 \\
\hline & $\begin{array}{l}\text { Fluktuatif } \\
\text { Kurs }\end{array}$ & $-22,846$ & 41,326 &,- 033 &,- 553 &, 584 & $-107,130$ & 61,439 \\
\hline & $\begin{array}{l}\text { Volume } \\
\text { Perdagangan } \\
\text { Saham }\end{array}$ & ,002 & ,001 & ,427 & 3,365 & ,002 & ,001 & ,004 \\
\hline
\end{tabular}

Berdasarkan Tabel 8, secara parsial nilai sig BI Rate sebesar 0,000 $<0,01$ maka BI rate memiliki pengaruh yang sangat signifikan. Hasil ini sesuai dengan teori yang ada. Dimana teori atau konsep menyatakan bahwa BI Rate bepengaruh negatif terhadap Indekss Harga Saham Gabungan (HSG). 
Inflasi memiliki nilai sig > 0,05 maka inflasi dan kurs tidak memiliki pengaruh yang signifikan terhadap IHSG. Hal ini menunjukkan bahwa inflasi tidak memiliki pengaruh secara langsungdalam mempengaruhi investor dalam berinvestasi di pasar saham. Faktor inflasi tidak menjadi bahan pertimbangan investor dalam berinvestasi.

Fluktuatif kurs tidak memiliki pengaruh terhadap IHSG dengan nilai sig sebesar 0,584 $>0,05$. Hal ini bertentangan dengan teori yang ada. Banyak teori atau konsep banyak teori atau konsep yang menyatakan bahwa kurs memiliki pengaruh yang negatif terhadap Indekss Harga Saham Gabungan (IHSG). Berdasarkan hasil ini, maka terdapat asumsi atas penyimpangan, hasil ini dapat disebabkan karena banyak investor ragu atau kurang tertarik dalam berinvestasi saham atau kebutuhan akan produk luar negeri sudah menjadi kebutuhan pokok. Oleh karena itu, investor akan mengabaikan nilai kurs.

Volume perdagangan saham memiliki pengaruh positif yang signifikat terhadap Indekss Harga Saham Gabungan (IHSG) dengan nilai sig 0,002<0,01. Hasil ini sesuai dengan teori atau konsep yang ada. Berdasarkan hasil penelitian Fikri (2012), saat volume perdagangan saham mengalami peningkatan, maka IHSG juga akan mengalami peningkatan yang akan diikuti dengan meningkatnya nilai pasar dan pada akhirnya meningkat kan kesejahteraan investor. Begitupun sebaliknya saat volume perdagangan saham mengalami penurunan, maka IHSG juga akan mengalami penurunan yang akan diikuti dengan menurunnya nilai pasar dan pada akhirnya kesejahteraan investor akan menurun yang dapat menyebabkan investor akan memilih untuk berinvestasi di luar saham.

\section{KESIMPULAN}

Berdasarkan teori maka hipotesis penelitian adalah sebagai berikut:

- BI rate memiliki pengaruh negatif yang sangat signifikan terhadap Indeks Harga Saham Gabungan (IHSG)

- Inflasi tidak memiliki pengaruh terhadap Indeks Harga Saham Gabungan (IHSG).

- Fluktuatif kurs tidak memiliki pengaruh terhadap Indeks Harga Saham Gabungan (IHSG).

- Volume perdagangan saham memiliki pengaruh positif yang signifikat terhadap Indekss Harga Saham Gabungan (IHSG.

- BI rate, inflasi, fluktutif kurs dan volume perdagangan saham perdagangan saham memiliki pengaruh yang sangat signifikan terhadap Indeks Harga Saham Gabungan (IHSG)

\section{DAFTAR PUSTAKA}

Budiantara Mohammad. (2012). Pegaruh Tingkat Suku Bunga, Nilai Kurs, Dan Inflasi Terhadap Indekss Harga Saham Gabungan di Bursa Efek Indonsia Periode Tahun 2005-2010. Jurnal Sosiohumaniora Vol.3, No. 3., ISSN: 2087-1899.

Fikri Mutakifi \& Andini Nurwulandari. (2012). Pengaruh Volume Perdagangan Saham, Nilai Tukar dan Indekss Hang Seng Terhadap Pergerakan Indeks Harga Saham gabungan. Jurnal Akutansi \& Bisnis. Vol 7, No. 2

Harum Alianty.(2016). Pengaruh Inflasi, Nilai Tukar, PDB, Harga Emas Dunia dan Harga Minyak Mentah Dunia Terhadap IHSG Periode 2009-2014. Jurnal Eksekutif Vol. 13., No. 2.

Handiani Sylvia. (2014). Pengaruh Harga Emas Dunia, Harga Minyak Dunia dan Nilai Tukar Dolar Amerika/Rupiah Terhadap Indekss Harga Saham Gabungan Pada Periode 2008-2013. E-Journal Graduate Unpar. Vol. 1, No. 1.

Kandir, Serkan Yilmaz (2008) "Macroeconomic Variables, Firm Characteristics and Stock Returns: Evidence from Turkey". International Research Journal of Finance and Economics ISSN 1450-2887 Issue 16. 
Kewal Suramaya Suci. (2012). Pengaruh Inflasi, Suku Bunga, Kurs, dan Pertumbuhan PDB terhadap Indekss Harga Saham Gabungan. Jurnal Economia Sekolah Tinggi Ilmu Ekonomi Musi Palembang Vol. 8. No.1.

Kowanda Dionysia dkk. (2015). Pengaruh Indekss Bursa Saham Asing dan Makro Ekonomi Terhadap Indekss Harga Saham gabungan Di Bursa Efek Indonesia Pada Tahun 20102014. Jurnal Manajemen Indonesia Vol. 15 No 3 Desember 2015.

Murwaningsari Etty. (2008). Pengaruh Volume Perdagangan Saham, Deposito dan Kurs Terhadap IHSG Beserta Prediksi IHSG (Model Garch dan Arima). Jurnal Ekonomi dan Bisnis Indonesia Vol. 23, No. 2, 2008, 178 - 195

Nofiatin Ike. (2013). Hubungan Inflasi, Suku Bunga, Produk Domestik Bruto, Nilai Tukar, Jumlah Uang Beredar, dan Indekss Harga Saham Gabungan (IHSG) Periode 20052011. Jurnal Aplikasi Manajemen Fakultas Ekonomi dan Bisnis Universitas Brawijaya. Vol. 11, No. 2.

Praphan, Wongbangpo, Subhash C. Sharma. (2002). Stock market and macroeconomic fundamental dynamic interactions: ASEAN-5 countries. Journal of Asian Economics, Elsevier, vol. 13(1), pages 27-51.

Samsul Mohamad. (2006). Pasar Modal dan Manajemen Portofolio. Erlangga : Jakarta

Sangkyun Park (1997). Rationality of negative Stock Price Responses to Strong Economics Activity. Journal Financial Analyst, Sept/Oct 1997

Tandelilin, Eduardus. (2001). Analisis Investasi dan Manajemen Portofolio. BPEF: Yogyakarta.

Widoatmojo Sawidji. (2005). Cara Sehat Investasi di Pasar Modal: Pengantar Menjadi Investor Profesional. Jakarta : PT Elek Media Komputindo.

Yogaswari, Dhira Dwijayanti dkk. 2010. The Effect of Macroeconomic Variables on Stock Price Volatility: Evidence from Jakarta Composite Index, Agriculture, and Basic Industry sector. DOI:10.7763. Vol 46. 


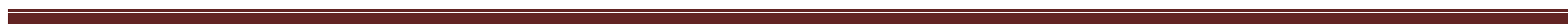
$\cdot$ 